\title{
Productivity of Young Aberdeen Angus and Hereford Breeds
}

\author{
Svetlana Sukhanova \\ Agribusiness Research Institute \\ Kurgan State Academy of Agriculture \\ named after T.S. Maltsev \\ Kurgan, Russia \\ nauka007@mail.ru \\ Nikolay Lushnikov \\ Department of Biotechnology \\ Kurgan State Academy of Agriculture \\ named after T.S. Maltsev \\ Kurgan, Russia \\ nikols1@ksaa.zaural.ru
}

\begin{abstract}
The article presents an analysis of the development of beef cattle industry in the Kurgan Region, as well as the research results of the productivity of beef cattle. The studies were carried out in the Kurgan Region farms in 2013-2014. During the research the young stock of the Aberdeen Angus and Hereford breeds were studied. It was stated that the young stock of Aberdeen Angus and Hereford breeds arethe main reserve of high-quality beef production in the Kurgan Region.The Aberdeen Angus breed cows showed the best productivity and economic efficiency in comparison with the Hereford breed cows. A significant effect of the breed influence on the productivity indicators was revealed: the average daily liveweightgain, the dry matter content in meat, the fat content in meat, the energy value of meat, the conversion rate of the exchange energy. To increase beef production in the Kurgan Region, it is recommended to breed animals of the Aberdeen Angus breed.
\end{abstract}

Keywords -cattle; breed; meat productivity

\section{INTRODUCTION}

Analysis of the current state and perspectives for the development of cattle breeding in Russia testifies to the growing importance of specialized beef cattle breeding $[1 ; 2 ; 3$; $4 ; 5 ; 7 ; 8 ; 9 ; 10 ; 11 ; 12 ; 13 ; 14]$. The revival of the beef cattle industry is attributed to the world's genetic resources of the Aberdeen Angus and Hereford breeds. The development of the beef cattle industry in the Kurgan Region is a promising area for solving economic and social problems of the region. Besides, it is a good possibility foreconomic breakthrough, and, as a result, a great chance for improvement of the quality of life of the population. The region processes all necessary conditions for the development of this industry, among which are as follows: natural forage lands, low-cost intensive pasture technologies, breeding stock in dairy herds for the development of new meat farms, feed grain [16]. The goal of this research was to substantiate the efficiency of breeding cattle for beef production in the conditions of the Kurgan Region.

\author{
Elena Alekseeva \\ Department of Biotechnology \\ Kurgan State Academy of Agriculture \\ named after T.S. Maltsev \\ Kurgan, Russia \\ AlekceevaElena@yandex.ru \\ Oksana Nazarchenko \\ Department of Biotechnology \\ Kurgan State Academy of Agriculture \\ named after T.S. Maltsev \\ Kurgan, Russia \\ nazarchenko-1972@mail.ru
}

\section{MATERIALS AND METHODS OF RESEARCH}

The studies were carried out on the basis of OOO Luch and family farm Pshenichnikova T.K. of the Kurgan Region in 2013-2014 with the involvement of young stock of Hereford and Aberdeen Angus breeds. The animals were selected basing on the method of balanced groups of analogs by the age and body weight. To study the dynamics of growth and development, two groups of animals (30 animals each) were formed: I - Aberdeen Angus bull-calves; II - Hereford bullcalves. Changes in the body weight were studied from birth to 18 months (inclusive). The absolute and average daily gains of animals were calculated according to the method of A. Mayonot modified by S. Brody. The meat productivity was determined by carrying out a control slaughter of three bulls from each group at the age of 18 months according to the method of All-Russian Research Institute of Metrological Service. When studying meat qualities of the animals, the following indicators were taken into account: live weight, slaughter weight, slaughter yield, chemical composition of meat. Under the conditions of State Budgetary Institution Kurgan Regional Veterinary Laboratory the chemical composition of meat was determined according to the generally accepted methods. The content of heavy metals and arsenic was identified on the basis of stripping voltammetry. Bothphysical and chemical properties of meat were established in the laboratory of the Department of General and Applied Chemistry of Kurgan State Academy of Agriculture named after T.S. Maltsev. The marbling of meat, the color of muscle tissue in the transverse section, the color of subcutaneous fat was determined in accordance with the reference scales, i.e. marbling, color of muscle tissue, and color shades of subcutaneous fat. The class of meat was identified according to GOST R 55445-2013.The area of the loin eye and the thickness of the subcutaneous fat were determined according to GOST R 55445-2013. Meat. High quality beef. Specifications. As far as the taste is concerned, the meat was subjected to the organoleptic evaluation. Such qualitative 
characteristics of meat as appearance, shape, color, as well as smell, taste, texture (tenderness, hardness) and juiciness were evaluated. The study of protein conversion and feed energy exchange into products was performed according to the method of L.K. Lepaye. The efficiency of beef production from meat breeds was determined according to the method of the Academy of Agricultural Sciences (current prices taken into account). The biometric processing of the obtained experimental data was carried out using the Excel and FACTOR_ANALYSER programs, as well as one-way ANOVA test.

\section{RESEARCH RESULTS}

The development of beef cattle breeding industry in the Kurgan Region began in 2007 when 159 heads of purebreed pedigree heifers of Hereford breed were brought from the Chelyabinsk Oblast to agricultural production cooperative Krutikhinsky. In 2008, OOO Suer acquired 412 female calves of Aberdeen Angus breed in Australia. In 2010, 759 female calves of Hereford breed were brought to ZAO Polesye; OOO Arman acquired 337 heads of Kazakh Whiteheadedin the Republic of Kazakhstan. In 2011, 60 female calves of Hereford breed were brought to Shatalin K.V.In December 2011, the family farmPshenichnikova T.K. purchased 45 breeding heifers of Aberdeen Angus breed. This breeding stock was used for breeding of specialized beef cattle in the Trans Urals. The targeted program of the Department of Agriculture and Processing Industry of the Kurgan Region the Development of Beef Cattle Breeding for 2011-2015facilitated the development of beef cattle breeding in the Kurgan Region [10; 12]. During this period, the livestock had increased from 2,089 heads to 6,531, including cows (from 666 to 2898 heads).Today, 73 farms, including 16 agricultural organizations and 57 familyoperated farms in the region are involved into stock-rearing. The number of beef cattle equalsto 16,550 heads, including 7,377 cows. The structure of the breed composition of cattle for beef production is as follows: $63.51 \%$ of Hereford cattle, $31.53 \%$ of Aberdeen Angus cattle, $2.72 \%$ of Auliekolsky cattle, $0.98 \%$ of Kazakh Whiteheaded, $0.65 \%$ of Kalmyk cattle, $0.33 \%$ Charolais cattle, $0.28 \%$ of Aubrac cattle.

In the course of the study, it was established that a large live weight at birth was observed in the Hereford breed of bulls $29.31 \mathrm{~kg}$. The difference with the Aberdeen Angus breed was $3.03 \mathrm{~kg}$. In the subsequent months of life, a significant superiority in the live weight was in animals of the Aberdeen Angus breed $(\mathrm{P}<0.001)$. Thus, in the weaning period, the indicator was $46.28 \mathrm{~kg}$ higher and at 18 months of age the indicator was $47.75 \mathrm{~kg}$ higher.

Variations in the average daily weight gain of beef cattle at different age periods were revealed.In the Hereford breed it varied from $570 \mathrm{~g}$ to $1,055 \mathrm{~g}$, in the Aberdeen Angus breed it varied from $837 \mathrm{~g}$ to $1,061 \mathrm{~g}$. According to the average daily weight gain the Aberdeen Angus breed exceeded the Hereford breed in the first month by $263 \mathrm{~g}(\mathrm{P}<0.001)$, in the second and third months - by $309 \mathrm{~g}(\mathrm{P}<0.001)$ and $225 \mathrm{~g}(\mathrm{P}<0.001)$, the fourth, fifth, sixth, seventh, eighth, fifteenth and seventeenth by $137 \mathrm{~g}(\mathrm{P}<0.05), 387 \mathrm{~g}(\mathrm{P}<0.001), 75 \mathrm{~g}(\mathrm{P}<0.05), 248 \mathrm{~g}$ $(\mathrm{P}<0.001), 94 \mathrm{~g}(\mathrm{P}<0.05), 33 \mathrm{~g}$ and $42 \mathrm{~g}$. Calves of the Hereford breed had an advantage on the average daily increase over the Aberdeen Angus calvesduring theninth, eleventh, twelfth, thirteenth, fourteenth, and eighteenth months of life by 31,108 $(\mathrm{P}<0.05), 2,8,72(\mathrm{P}<0.05)$ and $35 \mathrm{~g}$, respectively.

An absolute increase in the live weight from birth to weaning was as follows: in the Hereford bulls it was $152.07 \mathrm{~kg}$ and in the Aberdeen Angus it was $200.00 \mathrm{~kg}$. The difference in terms of the indicator comprised $47.93 \mathrm{~kg}(\mathrm{P}<0.001)$ in favor of the second one. An absolute increase in the live weight of animals from birth to 18 months was more in the Aberdeen Angus calves than in the Hereford by $43.41 \mathrm{~kg}(\mathrm{P}<0.001)$. The growth rate was also higher in the young stock of the Aberdeen Angus breed: in the period from birth to weaning, the difference was $28.69 \%(\mathrm{P}<0.001)$; from birth to 18 months the difference was $18.49 \%(\mathrm{P}<0.05)$.

The live weight of the Aberdeen Angus and Hereford bulls at the age of 18 months was $537.00 \mathrm{~kg}$ and $511.00 \mathrm{~kg}$, and after starvation before slaughter the indicator decreased by $17.30 \mathrm{~kg}$ and $6.30 \mathrm{~kg}$, respectively. The mass of young Aberdeen Angus carcasses was $318.00 \mathrm{~kg}$, includingmeat mass - $357.70 \mathrm{~kg}$, bones - $52.43 \mathrm{~kg}$; and Hereford carcasses - $307.00 \mathrm{~kg}$, includingmeat mass $-249.20 \mathrm{~kg}$, bones $-48.90 \mathrm{~kg}$. The live and pre-slaughter mass of Aberdeen Angus bulls exceeded the Hereford breed bulls by $26.00 \mathrm{~kg}$ and $15.00 \mathrm{~kg}$, respectively. The mass of carcass and the mass of meat were also greater for Aberdeen Angus bulls than for the Hereford bulls by $11.00 \mathrm{~kg}$ and $8.20 \mathrm{~kg}$, respectively. There were less bones in the carcass of the Hereford breed by $3.40 \mathrm{~kg}(\mathrm{P}<0.01)$. The slaughter yield of the Aberdeen Angus and Hereford animals was $61.2 \%$ and $60.8 \%$, respectively (a difference of $0.4 \%$ ). The increased value of inedible parts of carcass (the content of bones, cartilage and trimming) has slightly reduced the meatiness ratio. So, in the Aberdeen Angus breed, the indicator was 4.27 and in the Hereford breed the indicator was 4.33. The difference comprised $1.39 \%$ in favor of the second breed. The meat content per $1 \mathrm{~kg}$ of live weight was high and almost the same, i.e. $496.0 \mathrm{~g}$ for Aberdeen Angus calves and $493.7 \mathrm{~g}$ for Hereford breed (a difference of $0.46 \%$ ). The net gain of young stock of the Aberdeen Angus and Hereford breeds was $589 \mathrm{~g}$ and $568 \mathrm{~g}$. The difference between the breeds comprised $21 \mathrm{~g}$, or $3.57 \%$.

Over the entire period of growing (0-18 months) a smaller amount of energetic feed unit, energy exchange and digestible protein per $1 \mathrm{~kg}$ of an increase in live weight was consumed by the Aberdeen Angus calves - 6.23 energetic feed unit, $62.25 \mathrm{~mJ}$ and $540 \mathrm{~g}$. The difference with Hereford breed comprised 0.63 energetic feed unit (9.18\%), $5.99 \mathrm{~mJ}(8.78 \%)$ and $52 \mathrm{~g}(8.78 \%)$, respectively.

The analysis of chemical composition of meat showed that the Hereford breed bulls had a moisture content of $68.67 \%$, which corresponds to the norm for young animals. The amount of dry matter was equal to $31.33 \%$, including protein $-19.07 \%$, which is within the normal range; fat content was $11.30 \%$, which is significantly less than it should be in beef meat (on average $16 \%$ ); mineral substances amounted to $0.97 \%$. The ratios of the main nutrients were as follows: fat:protein $=0.59$ : $1,=$ protein: fat: moisture = 1: 1.67: $3.60,=$ moisture: dry matter $=2.19: 1$. In the Aberdeen Angus meat the moisture content was $73.13 \%$, which stays within the normal rangefor young animals. The amount of dry matter was $26.87 \%$, including protein $-18.63 \%$, fat $-7.43 \%$, and mineral substances 
- $0.80 \%$. The ratio of fat:proteincomprised $0.40: 1$; the ratio of protein: fat: moisturecomprised 1: $0.4: 4$; the ratio of moisture: dry matterwas 2.72: 1. A comparative analysis of chemical composition of meat of the considered breeds showed that a lower moisture content and a higher dry matter content was observed in the Hereford breed; the difference was $4.46 \%$. The meat of the Hereford bulls contained more protein and minerals compared to the Aberdeen Angus bulls, by $0.44 \%$ and $0.17 \%$, respectively. A lower fat content was observed in Aberdeen Angus bull meat; the difference was $3.87 \%$.

In these studies, the protein-fat ratio for the Hereford and Aberdeen Angus cattle was 1.71 and 2.51, respectively, which is significantly higher than the excepted rate for beef $(1.0-1.5$ [15]) due to high protein content and low fat content. At the same time, this indicator was significantly higher in animals of the Aberdeen Angus breed by $0.80(\mathrm{P}<0.001)$ compared to the Hereford bulls. The rate of early aging of meat of the Hereford calves was 0.457 and of the Aberdeen Angus it amounted to 0.367 at the rate of 0.400 . The reliability of the data is $\mathrm{P}<0.001$. The energy value of meat protein of the Hereford cattle was $78.17 \mathrm{kcal}$, and of the Aberdeen Angus cattle it amounted to $76.40 \mathrm{kcal}$. The energy value of fat comprised $105.09 \mathrm{kcal}$ and $71.36 \mathrm{kcal}$, respectively. The protein value of meat of Aberdeen Angus breedwas $5.04 \mathrm{kcal}$ or $6.6 \%$ higher than the fat value; the protein value of meat of the Hereford breed was lower than the fat value by $26.92 \mathrm{kcal}$ or $26.6 \%(\mathrm{P}<0.001)$. The energy value of $100 \mathrm{~g}$ of Hereford breed was $183.26 \mathrm{kcal}$ or $766.04 \mathrm{~kJ}$, and that of the Aberdeen Angus breed was 147.80 $\mathrm{kcal}$ or $618.70 \mathrm{~kJ}$, i.e. the energy value of $100 \mathrm{~g}$ of meat of Hereford breed was higher by $35.46 \mathrm{kcal}$, or $147.34 \mathrm{~kJ}$, than the analogues meat $(\mathrm{P}<0.001)$.

Thus, the analysis of chemical composition of the bull meat of the Hereford and Aberdeen Angus breeds showed that the meat of the carcasses of the experimental animals was of high quality, i.e. it was highly nutritious and low-calorie, which is important in modern food market.

The analysis of content of heavy metals (cadmium, mercury, lead) and arsenic in the bull meat of the Hereford and Aberdeen Angus breeds showed that the content of heavy metals was significantly lower than the maximum allowable concentration. Thus, the concentration of cadmium was about 28 times lower than the MRL; the concentration of lead was 7 times lower. The mercury and arsenic content was found to be $<0.01$ and $<0.005 \mathrm{mg} / \mathrm{kg}$, i.e. these data indicate that the concentration of toxicants is less than the MRL at least 3 and 20 times, respectively.

The results of histological studies of beef revealed that the samples of animal meat of Aberdeen Angus and Hereford breeds had a round muscle shape, their arrangement in the primary bundle was dense, and there were thin layers of intramuscular fat tissue in the connective tissue of carcass. The marbling of the meat of animals was assessed as good; the color of the meat was red, and the color of fat was white. The area of the loin eye of bulls of the Hereford and Aberdeen Angus breeds was 94.33 and $93.33 \mathrm{~cm}^{2}$; the thickness of subcutaneous fat was 1.83 and $1.80 \mathrm{~cm}$, respectively. The results of evaluation of these indicators allowed to assign class 1 to meat. A hydrogen indicator of meat samples from animals of both breeds showed that the $\mathrm{pH}$ was within the normal range -5.73 and 5.47.This value indicates that there were no deviations in the process of autolysis. The water-binding capacity of meat was also within the normal range $-54.33 \%$ and $52.33 \%$, which confirms the organoleptic analysis data on the juiciness and tenderness of meat.

Thus, the physical and chemical properties of the bull meat of the Hereford and Aberdeen Angus breeds were highly evaluated. With the animals of this breed one can get technologically qualitative beef.

The organoleptic analysis of beef showed that the appearance of meat obtained from young Aberdeen Angus breed was characterized as 'very pleasant'. Therefore, it received 8.00 points. The smell was 'pleasant'and scored 8.13 points. The taste was estimated at 7.63 points, which means 'quite tasty'. The consistency of meat was described as 'quite tender'. 7.00 points were assigned on this item. For its juiciness the meat received 6.75 points (it was described as 'not juicy'). The overall quality rating was 7.38 points; the meat was characterized as 'good' meat.For its appearance the meat from the animals of the Hereford breed received 8.63 points, i.e. 'very nice'. The smell was 'pleasant and strong' - 8.38 points. The taste of the sample was estimated at 8.63 points, which means 'tasty'. The consistency of meat was characterized as 'quite tender' - 8.00 points. For its juiciness the meat scored 8.00 points and was characterized as 'juicy'. The overall quality rating was 8.00 points; the meat was characterized as 'very good' meat.

The comparative analysis of meat of animals of Aberdeen Angus and Hereford breeds showed that both the appearance and smell were better in meat obtained from the Hereford, the score was higher by 0.63 and 0.25 compared to the meat of the Aberdeen Angus breed, respectively. The taste, consistency, juiciness of meat of young stock of the Hereford breed were rated higher than the Aberdeen Angus by 1.00, 1.00, 1.25 points $(\mathrm{P}<0.001)$, respectively. The overall score was also higher in meat of young Hereford breed -8.00 , i.e. by 0.62 and 0.33 points.

Thus, the animal meat of the Hereford breed received a higher rating, since it turned out to be tastier and juicier in comparison with the meat of animals of the Aberdeen Angus breed. In general, the meat of breeds under studyis tasty and of high quality.

To calculate the conversion rate of protein and the exchange energy of the diet into meat products, the amount of consumed protein and exchange energy for the entire period of growing calves was determined. Thus, the amount of protein was 294.33 $\mathrm{kg}$, and the exchange energy was $34332.6 \mathrm{~mJ}$. A higher content of protein and less fat were found in the meat of Aberdeen Angus bulls (48.00 and $19.14 \mathrm{~kg}$ ); the difference compared with the Hereford breed was 3.43 and $8.17(\mathrm{P} \leq 0.01) \mathrm{kg}$, respectively.

The protein and exchange energy conversion rates in the Aberdeen Angus group were 16.31\% and 4.56\%. For the Hereford bulls these numbers amounted to $16.15 \%$ and $5.57 \%$, i.e. the protein conversion rate was higher by $0.16 \%$ in the Aberdeen Angus group and the exchange energy conversion rate was higher by $1.01 \%$ for the Hereford group. 
The cost of $1 \mathrm{~kg}$ of liveweight gain of the Aberdeen Angus and Hereford cattle was $11,985.00$ and 13,542.00 rubles, respectively, i.e. the difference was $1,944.00$ rubles. The profitwas 8,234,09 rubles higherfrom the sale of the Aberdeen Angus. The profitability of beef production from Aberdeen Angus livestock was $20.98 \%$ and from the Hereford it was $7.07 \%$; the difference was $13.91 \%$.

A single-factor ANOVA established the strength of influence of the factor 'breed' on the indicators of productivity and meat quality. Thus, a significant influence of the factor $(\mathrm{P} \leq 0.01)$ was found on the average daily liveweightgain $(12.82 \%)$, dry matter content in meat $(42.27 \%)$, fat content in meat $(73.72 \%)$, energy value of meat $(58.95 \%)$, conversion rate of exchange energy (59.14\%). The reliable influence of this factor on other indicators was not defined.

To obtain more complete characteristics of the productivity of animals of breeds under study, a regression analysis of such indicators as average daily weight gain - formation intensity, live weight at weaning - pre-slaughter weight, and an absolute weight gain prior to weaning - mass of carcass was performed. The rates of correlation, elasticity, determination were taken into account.

It was established that in the bulls of Aberdeen Angus breed there is high and direct connection between such indicators as average daily weight gain - formation intensity $(r=0.76)$. At the same time, the rate of elasticity shows the dependence of these indicators, that is, when the value of one increases by $1 \%$, the second increases by $1.83 \%$, and the ratio of determination indicates that the intensity of formation is determined by average daily gain of $57.94 \%$.In the group of bulls of the Hereford breed, the relationship between these indicators is moderate and direct $(\mathrm{r}=0.44)$, i.e. with an increase in the average daily gain of $1 \%$, the intensity of formation increases by $1.12 \%$.In $19.10 \%$ of cases the change in the average daily gain leads to a change in the formation intensity. The ratios are statistically significant and the regression equation is statistically reliable; the results are reliable with $95 \%$ of probability

As far as the Aberdeen Angus bulls is concerned the link between indicators 'live weight at weaning - pre-slaughter weight' is very high and direct $(\mathrm{r}=1.00)$. An increase in live weight at weaning by $1 \%$ would lead to an increase in preslaughter weight by $1.17 \%$. A pre-slaughter mass depends on the live weight at weaning by $98.00 \%$ and it is determined by unaccounted factors by $2.00 \%$. In the Hereford young stock, the relationship between indicators is noticeable and direct $(\mathrm{r}=$ 0.57 ), an increase in live weight at weaning by $1 \%$ would lead to an increase in the pre-slaughter weight by $0.61 \%$. The preslaughter mass depends on live weight at weaning by $33.0 \%$ and by $67.0 \%$ it is determined by unaccounted factors.

Between such indicators as an 'absolute liveweightgain prior to weaning - mass of carcass' the link is very high and direct in bulls of Aberdeen Angus breed $(r=0.71)$; an increase in absolute weight gain prior to weaning by $1 \%$ would contribute to an increase in carcass weight by $3,12 \%$; the carcass weight depends on an absolute liveweightgain prior to weaning by $50.0 \%$, and by $50.0 \%$ it is determined by unaccounted factors. In bulls of the Hereford breed, the link between the considered traits is high and direct $(r=0.72)$. The elasticity ratio may help to defineliveweight gain prior to weaning by $1 \%$, the weight of the carcass would increase by $0.25 \%$, the carcass weight depends on an absolute liveweightgain prior to weaning by $51.0 \%$, and by $49.0 \%$ it is determined by unrecorded factors.

\section{CONCLUSION}

1. The main reserve of high-quality beef production in the Kurgan Region is the Aberdeen Angus and Hereford breed cows (31.53 and $63.51 \%$ of the total livestock, respectively).

2. Cows of the Aberdeen Angus breed showed better productivity and economic efficiency in comparison with the young stock of Hereford breed cows: an absolute increase in live weight from birth to weaning was 200.00 and $152.07 \mathrm{~kg}$, from birth to 18 months it was 498.27 and $447.49 \mathrm{~kg}$, a slaughter yield amounted to 61.2 and $60.8 \%$, a protein conversion ratio was 16.31 and $16.15 \%$, a profitability level was 20.98 and $7.07 \%$, respectively.

3. Over the entire growing period (0-18 months)cows of the Aberdeen Angus breed consumed fewer energetic feed unit, exchange energy and digestible protein per 1 $\mathrm{kg}$ of liveweight gain- 6.23 energetic feed unit, $62.25 \mathrm{~mJ}$ and $540 \mathrm{~g}$. The difference in comparison with the Hereford breed amounted to 0.63 energetic feed unit (9.18\%), $5.99 \mathrm{~mJ}(8.78 \%)$ and $52 \mathrm{~g} \quad(8.78 \%)$, respectively.

4. The meat of Aberdeen Angus and Hereford breed cows is highly nutritious and low-calorie. The energy value of $100 \mathrm{~g}$ of Hereford breed livestock was $183.26 \mathrm{kcal}$ or $766.04 \mathrm{~kJ}$, and the AberdeenAngus breed meat was $147.80 \mathrm{kcal}$ or $618.70 \mathrm{~kJ}$

5. A significant influence of the breed was revealed on the average daily weight gain $(12.82 \%)$, dry matter content in meat $(42.27 \%)$, fat content in meat $(73.72 \%)$, energy value of meat $(58.95 \%)$, the conversion rate of exchangeable energy $(59,14 \%)$.

6. There is high and direct, as well as moderate and direct link between the following indicators: the average daily liveweightgain and the formation intensity of Aberdeen Angus and Hereford bulls.In case of an increase in the value of one by $1 \%$, the second increases by 1.83 and $1.12 \%$; the formation intensity is determined on the basis of the average daily growth of 57.94 and $19.1 \%$, respectively. The links are high and direct, as well as visible and direct between the following indicators: the live weight at weaning and the pre-slaughter weight.The liveweightgain at weaning by $1 \%$ would lead to an increase in the pre-slaughter weight by 1.17 and $0.61 \%$; the pre-slaughter weight depends on live weight at weaning by 98.0 and $33.0 \%$, respectively. The link is very high and direct between the following indicators: an absolute liveweight gainprior to weaning and themass of carcass.An increase in absolute liveweight gainprior to weaning by $1 \%$ would increase the weight of carcass by 3.12 and $0.25 \%$; the weight of carcass depends on an 
absolute weight gain prior to weaning by 50.0 and $51.0 \%$, respectively.

7. To increase beef production in the Kurgan Region, it is recommended to breed cowsofthe AberdeenAngusbreed.

\section{References}

[1] M.A. Chasovshchikova et al,"Relationship between the genetic variants of kappa-casein and prolactin and the productive-biological characteristics of cows of the black-motley breed",Journal of Pharmaceutical Sciences and Research, 2017,vol. 9, No.7, pp. 1038-1044.

[2] I.M. Donnik et al, "Productivity and health markers for large cattle",International Journal of Green Pharmacy, 2017,vol. 11, No.S3, pp. S620-S625.

[3] A.V. Garkovenko et al,"Polymorphism of cattle microsatellite complexes",Journal of Pharmaceutical Sciences and Research, 2018, vol. 10, No. 6, pp. 1545-1551.

[4] A.G. Koshchaev et al, "Amino acid profile of meat of specialized beef breeds", Research Journal of Pharmaceutical, Biological and Chemical Sciences, 2016,vol. 7, No.5, pp. 670-676.

[5] G.A. Plutakhin, A.G. Koshchaev, I.M. Donnik,"Quality assessment of chicken meat by analysis-of-variance method", Research Journal of Pharmaceutical, Biological and Chemical Sciences, 2016,vol. 7, No. 3, pp. 2293-2299.
[6] S.F. Sukhanova et al,"Productive qualities of cattle depending on the breed", The Turkish Online Journal of Design, Art and Communication TOJDAC, March 2018 Special Edition, pp. 419-427.

[7] Kh.A. Amerkhanov et al,"The project Concepts of sustainable development of beef cattle in the Russian Federation until 2030", Bulletin of beef cattle, 2017, vol. 97, No. 1, pp. 7-12.

[8] I.M. Dunin,"Breeding resources of specialized beef cattle - the basis of intensive beef production in Russia", Zootekhniya, 2018, No. 2, pp. 2-4.

[9] A.G. Koschayev, S.Yu. Shuklin, I.V. Schukina,"Genetic diversity of cattle bred in the Krasnodar Territory", Agrarian Bulletin of Urals, 2017, vol. 166, No. 12, p. 5.

[10] V.V. Kulintsev, "Efficiency of growing and fattening bulls of Aberdeen Angus breed at different intensity of beef production", News of Orenburg State Agrarian University, 2018, vol. 72, No. 4, pp. 278-280.

[11] S.D. Tyulebaev et al, "The state of allelic forms of the capn1, cast genes and compatibility of different lines in the population of the Bredinsky meat type of Simmentals", Bulletin of Beef Cattle Breeding, 2017,vol. 98, No. 2, pp. 52-57.

[12] O.M. Sheveleva,"The results of the use of breed resources of cattle in the production of beef in the Tyumen Region", Bulletin of the AIC of Stavropol, 2018, vol. 30, No. 2, pp. 97-101.

[13] O.M. Sheveleva et al, "Meat cattle breeding of the Tyumen Region", World of Innovations, 2017, No. 1, pp. 112-117.

[14] I.V. Schukina,"Meat cattle breeding of the Krasnodar Territory", Bulletin of Bashkir State Agrarian University, 2014, vol. 29, No. 1, pp. 62-64.

[15] I.V. Schukina,"Energy and nutritional value of meat bulls of Aberdeen Angus and Hereford breeds", Proceedings of Kuban State Agrarian University, 2013,vol. 43, pp. 198-199. 